\title{
PROBLEMATIKA PEMBELAJARAN BAHASA ARAB DI SMP IT INSAN MULIA BATANGHARI
}

\author{
Defiani \\ UIN Sunan Gunung Djati Bandung \\ Jl. A. H. Nasution No. 105, Cipadung, Cibiru, \\ Kota Bandung, Jawa Barat 40614 \\ e-mail: khansasholihah845@gmail.com
}

\begin{abstract}
Abstrak
Dalam proses pembelajaran bahasa Arab masih saja membosankan, dan menakutkan bagi peserta didik. Bahwa ada yang berasumsi bahwa bahasa Arab secara fungsional kurang penting, lain halnya dengan bahasa Inggris. Hal tersebut kemudian menjadi problem dalam pembelajaran bahasa Arab, dimana peserta didik menjadi enggan mempelajari bahasa Arab dan akan berpengaruh terhadap minat belajar siswa. Pembelajaran bahasa Arab di kelas VIII Ar- Rasyid SMP IT Insan Mulia Batanghari sudah dilakukan secara optimal, namun dilihat dari hasil nilai pembelajaran bahasa Arab yang didapatkan masih di bawah standar belajar minimal, dengan melihat masalah tersebut peneliti mencoba untuk mencari solusi sehingga hasil pembelajaran sesuai dengan harapan. Sifat penelitian yang digunakan adalah deskriptif yaitu data yang memaparkan berupa kata-kata, gambar, dan bukan angka-angka. Penulis mencari dan mengumpulkan informasi dan serta data-data yang berkaitan dengan subyek dan obyek penelitian yang berisi tentang Problematika Pembelajaran Bahasa Arab di SMP IT Insan Mulia Batanghari Lampung Timur. Hasil menyatakan bahwa penyebab problematika di SMP IT Insan Mulia batanghari berasal darifaktor kemampuan siswa, faktor lingkungan sekolah, dan faktor lingkungan masyarakat dan keluarga. Sedangkan upaya guru dalam mengatasi problematika pembelajaran bahasa Arab yaitu dimulai dari peserta didik itu sendiri, didampingi oleh guru profesional, ditunjuang sarana dan prasarana yang memadai, dan dukungan dari lingkungan.
\end{abstract}

Kata Kunci: Problematika; Bahasa Arab; SMP IT. 


\section{A. Pendahuluan}

Bahasa Arab telah lama berkembang di Indonesia, dan telah diterapkan dalam pelajaran tingkat sekolah dasar dan tingkat perguruan tinggi baik swasta maupun negeri, tetapi mempelajari bahasa Arab tidak luput dari problema. Tidak hanya sebagai bahasa Agama, bahasa Arab dipelajari untuk memahami beberapa karya-karya para tokoh besar yang menggunakan bahasa Arab. ${ }^{1}$ Sebagai salah satu lembaga pendidikan Islam SMP IT Insan Mulia Batanghari, menjadikan bahasa Arab sebagai mata pelajaran wajib. Namun demikian dalam pembelajarannya tidak luput dari problema yang menghambat tujuan dari pembelajaran itu sendiri.

Pembelajaran bahasa Arab khususnya di SMP IT Insan Mulia Batanghari, khususnya kelas VIII Ar-Rasyid ditunjukkan agar siswa mampu menguasai bahasa Arab secara teori dan praktek untuk berkomunikasi, berinteraksi sosial, dan menambah khazanah keilmuan untuk memperdalam ilmu pengetahuan tentang kebahasaan sebagai alat komunikasi. Namun demikian, sesuai pengamatan awal di kelas VIII Ar-Rasyid, pembelajaran bahasa Arab tidak luput dari problema. Dalam proses pembelajaran bahasa Arab masih saja membosankan, dan menakutkan bagi peserta didik. Bahwa ada yang berasumsi bahwa bahasa Arab secara fungsional kurang penting, lain halnya dengan bahasa Inggris. ${ }^{2} \mathrm{Hal}$ di atas kemudian menjadi problem dalam pembelajaran bahasa Arab, di mana peserta didik menjadi enggan mempelajari bahasa Arab dan akan berpengaruh terhadap minat belajar siswa.

Temuan penelitian Akla menyatakan kemampuan berbahasa Arab pada peserta didik di sekolah-sekolah yang ada di Metro belum menggembirakan. Faktanya adalah guru belum melakukan optimalisasi penggunaan dan pengembangan metode dan strategi pembelajaran di samping penggunaan media. Selain itu, faktor pemicu ketidakberhasilan peserta didik dikarenakan belum tersedianya lingkungan bahasa yang diciptakan guru dan penanggung jawab Madrasah sebagai media belajar bahasa Arab sebagai bahasa kedua. $^{3}$

\footnotetext{
${ }^{1}$ Ulin Nuha, Metodologi Super Efektif Pembelajaran Bahasa Arab (Yogyakarta: Diva Press, 2012), h. 19.

${ }^{2}$ Observasi pembelajaran bahasa Arab kelas VIII Ar-Rasyid SMP IT Insan Mulia Batanghari pada tanggal 23 Februari 2018

${ }^{3}$ Akla Akla, "Pembelajaran Bahasa Arab Antara Harapan Dan Kenyataan (Survey Di Madrasah Kota Metro Tahun 2017)," An Nabighoh: Jurnal Pendidikan Dan Pembelajaran Bahasa Arab 19, no. 2 (2017), https://doi.org/10.32332/an-nabighoh.v19i2.998.
} 
Pembelajaran bahasa Arab di kelas VIII Ar- Rasyid SMP IT Insan Mulia Batanghari sudah dilakukan secara optimal, namun dilihat dari hasil nilai pembelajaran bahasa Arab yang didapatkan masih di bawah standar belajar minimal, dengan melihat masalah tersebut peneliti mencoba untuk mencari solusi sehingga hasil pembelajaran sesuai dengan harapan.

Berdasarkan latar belakang di atas penulis berusaha mengungkapkan masalah yang menjadi problema di SMP IT Insan Mulia Batanghari serta upaya untuk mengatasi dan mencari solusi dari permasalahan yang dituangkan dalam artikel dengan judul: Problematika Pembelajaran Bahasa Arab di SMP IT Insan Mulia Batanghari.

Penulis berharap problematika yang ada di SMP IT Insan Mulia Batanghari serta memberikan kontribusi pemikiran berupa solusi dari problema pembelajaran yang ada serta memberikan khazanah keilmuan bagi semua pihak khususnya bagi peneliti.

\section{B. Kerangka Teori}

\section{Problematika Pembelajaran Bahasa Arab Arab}

Problematika atau masalah adalah segala hal yang menuntut untuk dicari jawabannya atau diatasi keberadaannya. Masalah itu beragam, bisa berwujud kesulitan, rintangan, kesenjangan atau keraguan. Masalah adalah ketidaksesuaian antara harapan dan kenyataan.

Dalam hal ini yang akan dibahas adalah problem linguistik (Ilmu Bahasa) dan Problem Non Linguistik. ${ }^{4}$

a) Problematika linguistik (Ilmu bahasa)

1) Tata Bunyi

Sering dikenal dengan makharijul al huruf, tata bunyi ini kurang diperhatikan, makhorijul huruf ini hanya dipakai ketika membaca Al-qur'an, akan tetapi dalam proses pembelajarannya jang sekali digunakan sehingganya sering sekali yang kurang tepat dalam pengucapannya.

2) Kosakata

Banyak sekali istilah Arab yang sering dipakai ke dalam bahasa sehari-hari. sebenarnya, hal ini menguntungkan bagi pembelajar bahasa Arab di Indonesia karena beberapa kosakata

\footnotetext{
${ }^{4}$ Muljanto Sumardi, Pedoman Pengajaran Bahasa Arab pada Perguruan Tinggi/ IAIN (Jakarta: Proyek Pengembangan Sistem Pendidikan Agama, 1974), h. 129.
} 
sudah sering didengar dan sudah melekat dalam ingatan. Meskipun terkadang ada pergeseran arti, antara bahasa Indonesia dengan bahasa Arabnya, Semisal konjugasi.

3) Tata Kalimat

Tata kalimat bahasa Arab berbeda dengan bahasa Indonesia, yang lebih dikenal dengan I'rob, kesesuaian dengan tata urut kata.

4) Tulisan

Faktor lain yang dapat menghambat adalah tulisan yang berbeda dengan ejaan Indonesia, sehingga meski sudah lama mempelajari bahasa Arab, banyak yang masih salah dalam penulisannya. Hal ini harus menjadi kebiasaan atau paling tidak sering dilatih untuk imla' agar kemampuan menulis bisa terwujud.

b) Problem Non Linguistik

Berkaitan dengan problematika linguistik, karena perbedaan sosio-kultural antara bahasa Arab dan Bahasa Indonesia, terdapat perbedaan-perbedaan, ungkapan-ungkapan, Istilah-istilah, dan nama benda. Problematika yang kemudian timbul adalah ungkapanungkapan, istilah-istilah dan nama benda yang tidak terdapat dalam bahasa Indonesia dan tidak mudah dipahami pengertiannya oleh pelajar bahasa Arab di Indonesia, yang belum mengenal sedikitpun sosio kultural bangsa Arab. ${ }^{5}$

Adapun yang termasuk Problem Non Linguistik yaitu:

1) Guru

Guru adalah salah satu komponen manusiawi dalam proses belajar-mengajar. ${ }^{6}$ Dengan memperhatikan kebutuhan siswa akan hal ini dapat menumbuhkan minat atau motivasi anak didik dalam mencapai tujuan belajarnya.

2) Sarana Prasarana dan sebagainya

Sarana dan prasarana yang dibutuhkan adalah Media Pembelajaran, Buku, dan alat-alat yang menunjang dalam pembelajaran seperti LCD Proyektor dan lain-lain.

${ }^{5}$ Ahmad Izzan, Metodologi Pembelajaran Bahasa Arab (Bandung: Humaniora, 2011), h. 70.

${ }^{6}$ Sardiman, Interaksi Motivasi dan Belajar Mengajar (Jakarta: PT. Raja Ghafindo Persada, 2012), h. 125. 


\section{Pengertian Pembelajaran}

Berdasarkan pendapat aliran Behaviourism bahwa belajar merupakan perubahan tingkah laku sebagai akibat dari interaksi antara stimulus dan respon, terjadinya perubahan yang dialami siswa dalam hal kemampuannya untuk bertingkah laku dengan cara yang baru adalah hasil interaksi antara stimulus dan respon. ${ }^{7}$

Menurut Muhibbin Syah belajar adalah kegiatan yang berproses dan merupakan unsur-unsur yang sangat fundamental dalam setiap penyelenggaraan jenis dan jenjang pendidikan. ${ }^{8}$ Pemberdayaan diarahkan untuk mendorong pencapaian kompetensi dan prilaku khusus supaya setiap individu mampu menjadi pembelajar sepanjang hayat dan mewujudkan masyarakat belajar. ${ }^{9}$ Sedangkan WS Winkel mengatakan bahwa belajar adalah suatu aktivitas mental psikis yang berlangsung dalam interaksi aktif dengan lingkungan, yang menghasilkan perubahanperubahan dalam pengetahuan, pemahaman dan nilai sikap. Perubahan ini bersifat relatif konstan dan berbekas.

Dengan melihat pengertian di atas, belajar merupakan suatu proses yang terus-menerus dan harus dilalui dari yang awalnya tidak tahu menjadi tahu, dalam proses pembelajaran itu sendiri ada hal-hal yang dapat mengubah pola berpikir kita. Dalam hal ini kaitannya dengan proses pembelajaran bahasa Arab yang ada di kelas. Belajar bahasa memang berbeda dengan belajar ilmu lainnya, belajar bahasa akan lebih mudah dengan langsung praktek.

\section{Metode Penelitian}

Sifat penelitian yang digunakan adalah deskriptif yaitu data yang memaparkan berupa kata-kata, gambar, dan bukan angka-angka. Demikian laporan ini berisi kutipan-kutipan data member gambaran penyajian laporan. Data diperoleh dari naskah wawancara, data lapangan, foto, dan dokumen resmi lainnya. ${ }^{10}$

\footnotetext{
${ }^{7}$ Wahab Rosyidi dan Mamlu'atul Ni'mah, Memahami Konsep Dasar Pembelajaran Bahasa Arab (Malang: UIN Maliki Press, 2012), h. 13.

${ }^{8}$ Muhibbin Syah, Psikologi Pendidikan dengan Pendekatan Baru (Bandung: Remaja Rosdakarya, 2004), h. 89.

${ }^{9}$ Wina Sanjaya, Kurikulum dan Pembelajaran (Jakarta: Kencana, 2013), h. 215.

${ }^{10}$ Lexy J. Moleong, Metodologi Penelitian Kualitatif (Bandung: Rosdakarya, 2009), h. 11.
} 
Penulis mencari dan mengumpulkan informasi dan serta data-data yang berkaitan dengan subyek dan obyek penelitian yang berisi tentang Problematika Pembelajaran Bahasa Arab di SMP IT Insan Mulia Batanghari Lampung Timur. Sumber data dalam penelitian ini ada sumber data primer yaitu subyek yang diteliti, Guru, peserta didik, dan sekolah, subyek dan informasi penelitian, bagaimana ciri-ciri subjek dan informan itu sehingga kredibilitasnya dapat dijamin. Sumber data sekunder ini merupakan data penulis yang didapatkan dari orangtua siswa, serta lingkungan sekitar. Yaitu untuk mengetahui keadaan siswa, data sekunder memiliki manfaat yaitu seorang peneliti mampu memperoleh informasi.

Beberapa upaya pengumpulan data yang diperlukan, maka penulis menggunakan metode yang dapat mempermudah penelitian ini, antara lain: Observasi adalah Metode atau cara-cara menganalisis atau mengadakan pencatatan secara sistematis mengenai tingkah laku dengan mengamati siswa atau sekelompok siswa secara langsung. ${ }^{11}$ Metode interview adalah komunikasi langsung antara pewawancara dan yang diwawancarai untuk mengungkap persoalan yang diinginkan. ${ }^{12}$ Dokumentasi merupakan peristiwa yang telah berbentuk tulisan maupun gambar. Metode ini penulis gunakan untuk memperoleh data tentang:

1) Sejarah Singkat berdirinya SMP IT Insan Mulia

2) Visi dan Misi SMPIT Insan Mulia Batanghari

3) Keadaan siswa

4) Denah Lokasi

5) Keadaan Guru

6) Keadaan sarana dan Prasarana dan lainnya.

\section{Hasil dan Pembahasan}

Berdasarkan hasil penelitian yang dilakukan oleh peneliti dengan melakukan wawancara, observasi dan dokumentasi mengenai problematika pembelajaran bahasa Arab di SMP IT Insan Mulia Batanghari. Peneliti akan memaparkan gambaran umum mengenai penyebab serta upaya guru dalam mengatasi problematika pembelajaran sebagai berikut:

${ }^{11}$ Zakiah Daradjat, Metodik Khusus Pengajaran Agama Islam (Jakarta: Bumi Aksara, 2004), h. 214.

${ }^{12}$ Ramayulis, Metodologi Pendidikan Agama Islam (Jakarta: Kalam Mulia, 2010), h. 397. 
1. Penyebab Problematika di SMP IT Insan Mulia Batanghari

a. Kemampuan Siswa

Siswa di SMP IT Insan Mulia Batanghari sebagian besar berasal berasal dari ekonomi menengah ke atas dan tingkat kecerdasan mereka tidak terlalu tinggi, rendahnya minat, kurangnya motivasi peserta didik, sehingga hal ini menjadikan problem dalam pembelajaran bahasa Arab. ${ }^{13}$

b. Faktor Lingkungan Sekolah

Lingkungan Sekolah SMP IT Insan Mulia masih terjadi beberapa problem yaitu sarana dan prasarana seperti perpustakaan,yang menyediakan literatur bahasa Arab,masih sangat kurang, sehingga anak-anak menjadi kurang minat belajar bahasa Arab. Serta kurangnya peran serta guru dalam pembiasaan berdialog menggunakan bahasa Arab. Lingkungan masyarakatnya belum bisa dikatakan mendukung proses pembelajaran, sehingga anak-anak kurang terlatih dalam dialog berbahasa Arab.

c. Faktor Lingkungan Masyarakat dan Keluarga

Lingkungan masyarakat sekolah, di sekitar SMP IT Insan Mulia masyarakat sekitar belum terbiasa menggunakan bahasa Arab, bahkan dalam asrama pun belum lazim menggunakan bahasa Arab dalam kehidupan sehari-hari. Lingkungan asrama pun, tukang masak, contohnya, masih menggunakan bahasa daerah ketika berkomunikasi dengan anak-anak.

Mengenai lingkungan keluarga, orangtua sangat berperan dalam menyelesaikan masalah ini, akan tetapi mayoritas peserta didik ini tinggal di asrama, dan sangat kurang pantauan dari kedua orang tuanya, sehingga hal ini menjadi problem tersendiri bagi peserta didik.

2. Upaya guru dalam mengatasi problematika pembelajaran bahasa Arab. Upaya adalah sebagai berikut:

a. Peserta Didik

Upaya untuk peserta didik di SMP IT Insan Mulia Batanghari ini sebagai berikut, peserta didik adalah seorang yang masih perlu mendapatkan pendampingan dan motivasi dari yang

${ }^{13}$ Agus Waluyo, Wawancara dengan Kepala Sekolah SMP IT Insan Mulia Batanghari Lampung Timur, 10 Januari 2019. 
lebih dewasa sehingga bisa mengarahkan, membimbing, dan membina mereka ke arah yang lebih baik. Dari beberapa problem di atas, bahwa minat belajar peserta didik lebih bisa lebih optimal manakala guru mempunyai strategi belajar yang bagus sehingga peserta didik bisa termotivasi.

Untuk mengatasi masalah tersebut, sebelum memulai belajar mengajar, pertama masuk kelas, penulis perhatikan tingkat minatnya peserta didik, kemudian jika didapati problem demikian maka anak-anak diajak untuk permainan yang menimbulkan rileks, dan memberikan pertanyaan yang membuat mereka semangat, akan tetapi sesuai dengan materi pembelajaran, selain itu memberikan motivasi kepada peserta didik agar tidak merasa bosan, kemudian diberikan pertanyaan dengan tujuan untuk menarik minat peserta didik, selain itu juga menggunakan metode pembelajaran yang bervariasi, agar peserta didik tidak merasa bosan.

Peserta didik merasa pelajaran bahasa Arab ini kurang penting, sebab mata pelajaran ini tidak masuk ke dalam mata pelajaran yang di-UN-kan, sehingga guru bahasa Arab mencoba membuat keceriaan untuk meningkatkan daya minat terhadap pembelajaran bahasa Arab.

Untuk memotivasi biasanya guru menyediakan benda yang berupa hadiah, seperti buku-buku motivasi atau makanan ringan, terkadang juga berupa Al-Qur'an kecil bagi yang semangat mengikuti proses pembelajaran berlangsung, dengan harapan mereka memperhatikan dan mengikuti dengan baik proses pembelajaran tersebut. Dan melakukan pendekatan baik di kelas maupun di luar kelas.

Selain hal di atas, lingkungan bahasa mulai sedikit demi sedikit diterapkan, melalui program pondok dalam aktivitas seharihari, mulai membiasakan menggunakan bahasa Arab sebagai bahasa komunikasi mereka, sehingga peserta didik yang mayoritas tinggal di asrama memiliki kemampuan tambahan, yaitu berbahasa arab, meskipun masih dalam tahap belajar.

Kemudian bagi yang fullday, difasilitasi dengan ekskul bahasa Arab, yaitu dengan menerapkan sehari dalam seminggu, berbicara menggunakan bahasa Arab. Dengan melibatkan seluruh 
masyarakat sekolah, tanpa terkecuali, mulai dari kantin sekolah, penjaga koperasi dan seluruh yang ada di lingkungan sekolah ikut berpartisipasi dalam pembiasaan bahasa di lingkungan sekolah.

b. Guru

Seorang guru berperanan penting dalam proses pembelajaran. bagaimana guru bisa menyampaikan pelajaran agar bisa menarik dan mudah dipahami oleh peserta didiknya sehingga pelajaran bahasa Arab menyenangkan. Seorang guru harus memperhatikan penampilannya, karena penampilan guru sangat mempengaruhi minat peserta didik dalam belajar. Namun dalam pembelajaran bahasa Arab. guru harus bisa berbicara bahasa Arab dan bisa dicontoh oleh para peserta didik.

Selain problem di atas, masih ada beberapa problem yang lain yang perlu di cari solusi seperti kualitas guru, pengetahuan guru yang berbeda-beda. Untuk guru yang belum bagus khususnya dalam pelajaran Bahasa Arab ikut serta dalam musyawarah guru mata pelajaran bahasa Arab untuk peningkatan kemampuan guru Bahasa Arab. Dengan begitu SMP IT Insan Mulia Batanghari memiliki guru yang profesional baik dalam penyampaian materi maupun kurikulum serta mengelola peserta didik.

c. Sarana dan Prasarana

1) Sarana untuk menunjang pembelajaran

Penciptaan proses belajar mengajar yang kondusif membutuhkan banyak komponen, tidak hanya guru yang profesional, akan tetapi sarana dan prasarana juga harus dipenuhi seperti buku-buku penunjang bahasa Arab serta perpustakaan sekolah. Untuk mengedepankan kompetensi dan karakter peserta didik membutuhkan media pembelajaran yang memadai dan sesuai dengan materi yang sedang diajarkan.

Berdasarkan hasil wawancara dengan guru bahasa Arab di SMP IT Insan Mulia yaitu Ganjar Eko Utomo yang berpendapat bahwa untuk pembelajaran di kelas agar anak tidak bosan atau lebih bersemangat dalam belajar, sangat membutuhkan alat bantu seperti LCD, laptop, dan beberapa perangkat lain yang mendukung pembelajaran bahasa Arab. Akan tetapi di SMP IT ini masih kurang sekali dalam 
penyediaannya, untuk bisa menggunakan LCD harus bersaing dengan guru mata pelajaran yang lainnya.

Sarana dan prasarana dalam proses pembelajaran sangat dibutuhkan agar materi yang disampaikan dapat tersalurkan dengan baik. Dan seharusnya seorang guru memiliki media pembelajaran masing-masing agar memudahkan dalam proses pembelajaran. Adapun dari segi sarana dan prasarana untuk pembelajaran bahasa Arab perlu perbanyak referensi buku yang mendukung pembelajaran. ${ }^{14}$

2) Sarana dan prasarana untuk beribadah

Ibadah merupakan kewajiban setiap muslim, baik lakilaki maupun perempuan. Selain dalam proses pembelajaran, dalam beribadah pun perlu sarana dan prasarana yang dapat mendukung terlaksananya ibadah dengan baik. berdasarkan hasil wawancara dengan Mulyono selaku Mudir pondok, (boarding school) SMP IT Insan Mulia, berpendapat bahwa Sarana penunjang untuk beribadah sangat minim sekali, terutama untuk tempat wudhu akhwat, mukena yang lusuh dan bau, serta masjid yang sering kotor karena debu. Karena masjid adalah tempat untuk beribadah peserta didik, jadi masjid juga merupakan sarana untuk membentuk karakter peserta didik, maka dari itu seharusnya masjid harus memiliki fasilitas yang lengkap dan memadai. ${ }^{15}$

Kelengkapan sarana dan prasarana dalam beribadah merupakan hal yang harus diperhatikan. Karena itu merupakan media untuk membantu terbentuknya karakter peserta didik, dalam hal ibadah.

d. Lingkungan

Semua lingkungan masyarakat berperan penting, dalam hal ini pembelajaran bahasa Arab. Upaya untuk mengatasi problem yang terjadi pada lingkungan di SMP IT Insan Mulia Batanghari Lampung Timur, harus ada kerja sama antara warga sekolah dan.

${ }^{14}$ Ganjar Eko, Wawancara dengan guru bahasa Arab SMP IT Insan Mulia Batanghari Lampung Timur, 11 Januari 2019.

${ }^{15}$ Mulyono, Wawancara dengan Mudir Pondok SMP IT Insan Mulia Batanghari Lampung Timur, 11 Januari 2019. 
Lingkungan dalam proses pembelajaran bahasa Arab di SMP IT Insan Mulia Batanghari Lampung Timur.

Tidak hanya itu, keluarga berperan dan perlu diperhatikan, terutama anak-anak yang fullday, karena lingkungan keluarga sangat berpengaruh sekali pada pemahaman anak-anak terhadap bahasa Arab, untuk memantau sampai sejauh mana kemampuan anak-anak dalam menerapkan apa yang sudah mereka pelajari dalam kehidupan sehari-hari, tidak hanya menjadi tanggung jawab guru seorang diri, perlu adanya kerja sama sehingga keberhasilan pembelajaran bahasa Arab dapat terwujud, sesuai dengan keinginan bersama.

Kurangnya perhatian orangtua terhadap anaknya dalam hal pembelajaran bahasa Arab khususnya, perlu adanya solusi, dengan cara mengumpulkan wali murid dengan guru di sekolah untuk mengadakan pelaporan hasil belajar anak-anak, diharapkan dengan seperti itu orangtua bisa mengetahui hasil belajar, khususnya dalam pembelajaran bahasa Arab.

\section{E. Simpulan}

Adapun penyebab problematika pembelajaran bahasa Arab di SMP IT Insan Mulia Batanghari berasal dari beberapa faktor diantaranya kemampuan siswa, faktor lingkungan sekolah, dan faktor lingkungan masyarakat dan keluarga. Sedangkan upaya guru dalam mengatasi problematika pembelajaran bahasa Arab yaitu dimulai dari peserta didik itu sendiri, kemudian dilakukan pendampingan oleh guru profesional, ditunjuang sarana dan prasarana yang memadai, serta dukungan dari lingkungan masyarakat sekitar. 


\section{Daftar Pustaka}

Akla, Akla. "Pembelajaran Bahasa Arab Antara Harapan Dan Kenyataan (Survey Di Madrasah Kota Metro Tahun 2017)." An Nabighoh: Jurnal Pendidikan Dan Pembelajaran Bahasa Arab 19, no. 2 (2017). https://doi.org/10.32332/an-nabighoh.v19i2.998.

Daradjat, Zakiah. Metodik Khusus Pengajaran Agama Islam. Jakarta: Bumi Aksara, 2004.

Eko, Ganjar. Wawancara dengan guru bahasa Arab SMP IT Insan Mulia Batanghari Lampung Timur, 11 Januari 2019.

Izzan, Ahmad. Metodologi Pembelajaran Bahasa Arab. Bandung: Humaniora, 2011.

Moleong, Lexy J. Metodologi Penelitian Kualitatif. Bandung: Rosdakarya, 2009.

Mulyono. Wawancara dengan Mudir Pondok SMP IT Insan Mulia Batanghari Lampung Timur, 11 Januari 2019.

Nuha, Ulin. Metodologi Super Efektif Pembelajaran Bahasa Arab. Yogyakarta: Diva Press, 2012.

Ramayulis. Metodologi Pendidikan Agama Islam. Jakarta: Kalam Mulia, 2010.

Rosyidi, Wahab, dan Mamlu'atul Ni'mah. Memahami Konsep Dasar

Pembelajaran Bahasa Arab. Malang: UIN Maliki Press, 2012.

Sanjaya, Wina. Kurikulum dan Pembelajaran. Jakarta: Kencana, 2013.

Sardiman. Interaksi Motivasi dan Belajar Mengajar. Jakarta: PT. Raja

Ghafindo Persada, 2012.

Sumardi, Muljanto. Pedoman Pengajaran Bahasa Arab pada Perguruan

Tinggi/ IAIN. Jakarta: Proyek Pengembangan Sistem Pendidikan

Agama, 1974.

Syah, Muhibbin. Psikologi Pendidikan dengan Pendekatan Baru. Bandung:

Remaja Rosdakarya, 2004.

Waluyo, Agus. Wawancara dengan Kepala Sekolah SMP IT Insan Mulia

Batanghari Lampung Timur, 10 Januari 2019. 